\title{
The Compatability of Hly Factor, a Transmissible Element which Controls $\alpha$-Haemolysin Production in Escherichia coli
}

\author{
By C. MONTI-BRAGADIN, LILIANA SAMER, \\ G. D. ROTTINI AND BIANCA PANI \\ Institute of Microbiology, University of Triest, Triest, Italy,
}

(Received 16 May 1974; revised I September 1974)

The transmissible nature of the genetic factor in Escherichia coll, which controls $\alpha$-haemolysin production, was recognized by Smith \& Halls ( 1967 ). The element responsible was termed Hly. The $\mathrm{fi}^{+}$character of Hly factor was described at the same time.

Goebel \& Schrempf (1971) demonstrated the presence in the cytoplasm of a hacmolytic $E$. coli strain of a covalently-closed circular DNA molecule with a contour length of $29.5 \pm 0.5 \mu \mathrm{m}$, which was transferred to non-haemolytic strains together with the haemolytic character. Therefore this DNA species represents the Hly factor. However, Hly factor was not taken into account by Hedges \& Datta (1972), who classified the F-like plasmids into four compatibility groups. A further group of F-like plasmids was subsequently added by Naomi Datta in 1974 (personal communication), Folac being the prototype of it (Falkow \& Baron, 1962).

In the present paper we show that Hly factor determines the production of F-type pili and that it is compatible with F-like plasmids of all the five groups previously described.

Escherichia coli strain P212 carrying Hly factor was received from $\mathrm{H}$. Williams Smith.

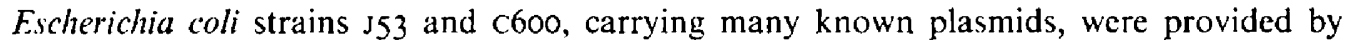
Naomi Datta. R7, R89 and RI20, three F-like R factors recently identified in Triest, were also used.

Crosses were carried out by mixing equal numbers (about $2 \times 10^{7} / \mathrm{ml}$ ) of donor and recipient cells in nutrient broth, which was subsequently incubated overnight at $37{ }^{\circ} \mathrm{C}$. Colonies were then counted on nutrient or blood agar containing, if required, appropriated amounts of different antibiotics to define the number of donor, recipient and recombinant cells. Colonies producing colicin were identified by standard techniques. To test for the compatibility of plasmids, recombinant clones were purified on nonselective medium and tested by replica plating for the presence of each plasmid.

The $\mathrm{f}^{\mathrm{t}}$ character of $\mathrm{Hly}$ factor was confirmed in our study. Moreover, we could show that $E$. coli strains carrying the Hly factor allowed a small but definite increase in the titre of MS2 phage (Davis, Strauss \& Sinsheimer, I96I). This demonstrates that Hly controls the synthesis of F-pili.

Being not perfectly clear from the data reported by Smith \& Linggood (1970) and Smith \& Heller (1973) whether Hly is self-transmissible or mobilized by the F factor, we tested different strains of $E$. coli KI2 F, which had acquired the Hly factor from $E$. coli strain P2 I 2, for sensitivity to the female-specific phages $T_{7}$ and $\phi_{2}$ (Makela, Makela \& Soikkeli, 1964; Cuzin, 1965). The Hly-positive bacteria remained sensitive to these phages. Hly factor was transmissible from these bacteria by conjugation. It appears, therefore, that at least the Hly factor used in the present study, for which we propose the name of $\mathrm{Hly}-\mathrm{P}_{2} \mathrm{I}_{2}$, is selftransmissible. 
Table I. Compatibility of Hly-P2 2 factor

\begin{tabular}{|c|c|c|c|c|c|c|}
\hline \multirow[b]{2}{*}{$\begin{array}{l}\text { Plasmid } \\
\text { in the } \\
\text { donor }\end{array}$} & \multirow[b]{2}{*}{$\begin{array}{l}\text { Plasmid } \\
\text { in the } \\
\text { recipient }\end{array}$} & \multirow[b]{2}{*}{$\begin{array}{l}\text { Compatibility } \\
\text { group of } \\
\text { plasmid* }\end{array}$} & \multirow[b]{2}{*}{$\begin{array}{c}\text { Frequency of } \\
\text { transfer/recipient } \\
\text { cell }\end{array}$} & \multicolumn{3}{|c|}{$\begin{array}{l}\text { Analysis of recombinants } \dagger \\
\text { (Number of colonies tested) }\end{array}$} \\
\hline & & & & Total & $\begin{array}{c}\text { With } \\
\text { Hly-P212 }\end{array}$ & $\begin{array}{l}\text { With } \\
\text { the other } \\
\text { plasmid }\end{array}$ \\
\hline \multirow[t]{7}{*}{ Hly-P2I 2} & - & - & $4 \times 10^{-1}$ & 一 & - & - \\
\hline & Flac & FI & $I \times 10^{-1}$ & 136 & 136 & 136 \\
\hline & $\mathrm{R}_{386}$ & FI & $1 \times 10^{-1}$ & 92 & 92 & 92 \\
\hline & $\mathrm{R}_{136}$ & FII & $I \times 10^{-1}$ & 102 & 102 & 102 \\
\hline & ColB-K98 & FIII & $<10^{-6}$ & \multicolumn{3}{|c|}{ No recombinant formed } \\
\hline & $\operatorname{Rr} 24$ & FIV & $4 \times 10^{-2}$ & 28 & 28 & 28 \\
\hline & Folac & FV & $2 \times 10^{-2}$ & 154 & I 54 & I54 \\
\hline \multirow[t]{2}{*}{ Flac } & - & FI & $\mathrm{I} \times 10^{-1}$ & - & - & - \\
\hline & Hly-P2I 2 & FI & $\mathrm{I} \times 10^{-1}$ & 163 & I 63 & 163 \\
\hline \multirow[t]{2}{*}{$R_{386}$} & - & FI & $4 \times 10^{-1}$ & $\cdots$ & - & 一 \\
\hline & Hly-P2 I 2 & FI & $8 \times 10^{-5}$ & 24 & 24 & 24 \\
\hline \multirow[t]{2}{*}{$R I 36$} & $-\cdots$ & FII & $\mathrm{I} \times \mathrm{IO}^{-1}$ & - & - & - \\
\hline & Hly-P2I 2 & FII & $2 \times 10^{-3}$ & 63 & 63 & 63 \\
\hline \multirow[t]{2}{*}{ ColB-K98 } & - & FIII & $2 \times 10^{-1}$ & - & - . & $\cdots$ \\
\hline & Hly-P2I 2 & FIII & $2 \times 10^{-2}$ & I 88 & I 88 & 188 \\
\hline \multirow[t]{2}{*}{ R.24 } & - & FIV & $I \times 1 O^{-2}$ & - & - & - \\
\hline & Hly-P2 I 2 & FIV & $2 \times 10^{-7}$ & 17 & 17 & I 7 \\
\hline \multirow[t]{2}{*}{ Folac } & $\cdots$ & FV & $1 \times 10^{-1}$ & 一 & 一 & - \\
\hline & Hly-P2 I 2 & FV & $1 \times 10^{-3}$ & 226 & 226 & 226 \\
\hline
\end{tabular}

* Other than Hly-P2 I 2.

$\dagger$ Derived from 3 to 8 purified clones for each cross.

Hly-P2 2 factor does not control resistance to any known antibiotic or production of any known colicin, since cells, which acquire the haemolytic character in crosses between $\mathrm{Hly}^{+}$ and $\mathrm{Hly}^{-}$strains, do not modify their antibiotic sensitivity pattern or become producers of colicin.

Crosses between strains carrying the Hly-P2I2 factor and plasmids representative of groups FI, FII, FIII, FIV and FV always yielded stable doubles (Table I). Stable doubles were also formed between Hly-P2 22 and three recently identified F-like R factors, whose compatibility behaviour will be reported elsewhere. Finally, Hly-P2I2 was found to be compatible with $\mathrm{R}$ factors of groups $\mathrm{A}, \mathrm{C}, \mathrm{I} \alpha, \mathrm{I} \beta, \mathrm{I} \omega, \mathrm{N}, \mathrm{P}, \mathrm{T}$ and $\mathrm{W}$ (Hedges, 1974). In each case, Hly-P2 2 and the other factor coexisted in doubles as separate entities, as shown by their independent transmission in conjugation tests.

Our data support the conclusion of Hedges \& Datta (1973) that there is no strict correlation between compatibility and surface exclusion. In fact, Hly-P2r2 is compatible with all the F-like plasmids we tested, but in some crosses exclusion was very efficient, mainly when $\mathrm{R}_{3} 86$ or $\mathrm{R}_{1} 24$ was introduced into a strain carrying Hly-P2 I 2. ColB-K98 excluded Hly-P2 I 2 so efficiently that no recombinant was obtained in this cross. No case of exclusion was recorded in crosses between Hly-P2I 2 and the plasmids of the non-F-like groups.

Our results demonstrate that the Hly-P2I 2 factor, which controls the production of Ftype pili, is compatible with all the F-like plasmids tested; it can therefore be considered the first member of a new compatibility group, which according to Hedges \& Datta (I972) should be called FVI. 


\section{REFERENCES}

CuzIN, F. ( (1965). Un bactériophage spécific du type séxuel $\mathrm{F}^{-} \mathrm{d}^{\prime}$ Escherichia coli $\mathrm{K}$ 2 . Comptes rendus hebdomadaire des séances de l'Académie des sciences 260, 6482-6485.

Davis, J. E., Strauss, J. H. \& Sinsheimer, R. L. (1961). Bacteriophage MS2: another RNA phage. Science, New York 134, 1427.

FaLkow, S. \& BARON, L. S. (1962). Episomic element in a strain of Salmonella thyphosa. Journal of Bacteriology 84, 58I-589.

GotBeL, W. \& SCHREMPF, H. (1971). Isolation and characterization of supercoiled circular deoxyribonucleic acid from beta-haemolytic strains of Escherichia coli. Journal of Bacteriology 106, 31 I-317.

Hedges, R. W. (1974). R factors from Providence. Journal of General Microbiology 8r, I7I-I 8I.

Hedges, R. W. \& DatTA, N. (1972). Ri24, an $f^{+}$R factor of a new compatibility class. Journal of General Microbiology 7I, 403-405.

Hedges, R. W. \& DatTa, N. (1973). Plasmids determining I pili constitute a compatibility complex. Journal of General Microbiology 77, 19-25.

Makela, O. P., Makela, H. \& Solkkeli, S. (1964). Sex specificity of bacteriophage T7. Annales medicinae experimentalis et biologiae Fenniae 42, I88-195.

Smith, H. W. \& Halls, S. (I967). The transmissible nature of the genetic factor in Escherichia coli that controls haemolysin production. Journal of General Microbiology 47, I53-161.

Smith, H. W. \& Heller, E. D. (1973). The activity of different transfer factors introduced into the same plasmid-containing strain of Escherichia coli KI 2. Journal of General Microbiology 78, 89-99.

SMith, H. W. \& LingGoOd, M. A. (1970). Transfer factors in Escherichia coli with particular regard to their incidence in enteropathogenic strains. Journal of General Microbiology 62, 287-299. 